\title{
KESETARAAN GENDER MENURUT PERFEKTIF ISLAM
}

\author{
Tri Wahyudi Ramdhan, M.Pd.I
}

\begin{abstract}
Abtraksi
Pemikiran Islam tradisional secara general memberikan keterbatasan peran perempuan sebagai istri dan ibu. Berdasarkan pandangan teks dan literature Islam klasik tersebut masih terlihat bahwa kaum perempuan masih termarjinalkan, atau dengan kata lain perempuan masih berada di bawah dominasi laki-laki. Oleh karenanya, wacana atau konstruk perempuan harus menurut kehendak teks. Tak dapat dipungkiri bahwa penafsiran ulama-ulama klasik tentang konsep persamaan laki-laki dan perempuan jika dilihat dari perspektif saat ini bisa saja dinilai sebagai bias. Sebab penafsiran-penafsiran masa lampau itu tidak dapat dilepaskan dengan konteks sosio-historis saat itu. Berangkat dari permasalahan tersebut di atas maka tulisan ini ingin melihat dan menganalisa bagaimana konsep yang ditawarkan dan dikemukakan Islam dalam memandang kesetaraan gender

antara laki-laki dan perempuan Kata
\end{abstract}

Kunci: Gender, Perfektif Islam

\section{Pendahuluan}

Saat ini gender masih menjadi isu sentral yang kerap dibicarakan. Kekeliruan dalam memahami dan mengartikan istilah gender masih sering terjadi. Sebagaimana isu-isu lainnya seperti Demokrasi, HAM, Civil Society, Gender termasuk isu baru dan 
diperkirakan menjadi discourse di Indonesia barulah pada pertengahan tahun 1990-an. Sedangkan kesetaraan gender berarti kesamaan kondisi bagi laki-laki dan perempuan untuk memperoleh kesempatan serta hak-haknya sebagai manusia. Kesetaraan gender meliputi penghapusan diskriminasi dan ketidakadilan struktural, baik terhadap laki-laki maupun perempuan. Dengan keadilan gender berarti tidak ada pembakuan peran, beban ganda, subordinasi, marginalisasi dan kekerasan terhadap perempuan maupun laki-laki. Terwujudnya kesetaran dan keadilan gender ditandai dengan tidak adanya diskriminasi antara perempuan dan laki-laki, dan dengan demikian mereka memiliki akses dan kesempatan berpartisispasi.

Kaum perempuan seringkali kurang mendapatkan kesempatan yang cukup untuk berkiprah dalam kehidupan sosial bila dibandingkan dengan laki-laki. Hal ini terjadi karena masih lekatnya ketidakadilan gender dalam masyarakat yang terjelmakan dalam marginalisasi atau proses pemiskinan ekonomi, subordinasi atau anggapan yang bersifat menyepelekan (tidak penting) kepada kaum perempuan, bahkan kekerasan (violence) termasuk dalam hal bekerja atau justru beban kerja yang lebih panjang atau lebih banyak (double burden). Bentuk ketidakadilan gender ini tidak dapat dipisah-pisahkan karena saling terkait dan berhubungan, serta saling mempengaruhi secara dialektis. Tidak ada satu pun bentuk ketidakadilan gender yang lebih penting dan lebih esensial dari ketidakadilan yang lain.

Begitu juga dalam bidang keagamaan, khususnya masyakarat Islam. Fenomena ketidakadilan gender dalam Islam ternyata lebih menunjukkan adanya kesewenang-wenangan dan penindasan terhadap kaum perempuan. Boleh jadi hal ini merupakan akibat dari pola budaya dan sistem masyarakat muslim yang mayoritas bercorak patrialkal, struktural dan subordinatif. Hal ini dapat dilihat dalam sejarah masyarakat muslim. Sempitnya ruang gerak bagi kaum perempuan muslim terjadi justru setelah Islam mengalami perkembangan pesat dengan wilayah kekuasaan yang luas. Dalam 
masyarakat muslim Arab pra-Islam dan Islam masa awal, kaum perempuan pada umumnya dapat beraktualisasi secara bebas. Namun, kemudian terjadi pergeseran pandangan terhadap perempuan diantaranya karena interaksi budaya, kepentingan politik dan ekonomi serta interpretasi atau penafsiran terhadap teksteks alQur'an.

Apabila gender dipahami sebagai konstruksi sosial, maka agama dipandang sebagai salah satu institusi yang membentuk pandangan yang streotif terhadap perempuan. Dalam hal ini, Islam dituduh sebagai agama yang paling tidak adil memperlakukan perempuan. Pandangan-pandangan yang bias gender telah mengakar dalam wacana dan praktek keberagamaan dengan atau tanpa legitimasi ajaran agama, akan menjadi lebih sulit untuk dibongkar atau didekonstruksi jika peran-peran dari tiap elemen masyarakat terutama kyai sebagai tokoh agama tidak diperhitungkan.

Dalam konsep Islam, terutama merujuk kepada al-Qur'an, konsep keseteraan gender mengisyaratkan 2 (dua) pengertian. Pertama, al-Qur'an mengakui martabat pria dan wanita dalam kesejajaran tanpa membedakan jenis kelamin. Kedua, pria dan wanita mempunyai hak dan kewajiban yang sejajar disegala bidang. akan tetapi pandangan inferior bahwa perempuan adalah makhluk yang lemah juga disosialisasikan atas nama agama.

Memahami ajaran agama melalui penafsiran al-Qur'an sebagaimana yang ditafsirkan ulama salaf tidak sepenuhnya benar. Artinya kondisi sosial masyarakat tidak lagi seperti pada masa dulu. Bukan saja karena al-Qur'an harus diyakini berdialog dengan setiap generasi, namun juga harus dipelajari dan dipikirkan. Sementara hasil pemikiran (termasuk penafsiran) selalu dipengaruhi oleh beberapa faktor, misalnya kondisi pengalaman, ilmu pengetahuan, latar belakang pendidikan yang berbeda dari satu generasi ke generasi lainnya, bahkan antara pemikir satu dan pemikir lainnya pada suatu generasi. 
Dalam khazanah demokrasi terdapat aliran yang mngusung semboyan kesetaraan gender dan persamaan hak antara laki-laki dan perempuan di segala bidang. Dalam perkembangannya, merekaberhasil mempengaruhi pemikiran dunia. Bahkan disebagian negara-negara islam, aliran ini mulai digemari. Karena bilaa dilihat sepintas, nilai-nilai emansipasi yang menjadi ruh perjuangan mereka sangatlah menjajikan bagi terhapusnya diskriminasi wanita dan bagi terciptanya keadilan yang tidak mempermasalaahkan perbedaan gender. Lebih lanjut, para tokoh feminis muslim juga melakukan kritik terhadap interpretasi teksteks suci yang diputarbalikkan sedemikian rupa sehingga berakibat munculnya kehidupan yang eksploitatif dan diskriminatif terhadap perempuan. Kritik tersebut terutama ditujukan terhadap tafsiran fikih Islam yang memposisikan wanita pada posisi yang subordinat

Beberapa teori mengenai kesetaraan peran laki-laki dan perempuan yang umumnya dikemukakan oleh para feminis kontemporer didasarkan pada pertanyaan mendasar "apa peran perempuan?" Secara esensial ada empat jawaban untuk pertanyaan tersebut. Pertama, bahwa posisi dan pengalaman perempuan dari kebanyakan situasi berbeda dari yang dialami laki-laki dalam situasi tu. Kedua, posisi perempuan dalam kebanyakan situasi tak hanya berbeda, tetapi juga kurang menguntungkan atau tak setara dibandingkan dengan laki-laki. Ketiga, bahwa situasi perempuan harus pula dipahami dari sudut hubungan kekuasaan langsung antara laki-laki dan perempuan. Perempuan "ditindas", dalam arti dikekang, disubordinasikan, dibentuk, dan digunakan, serta disalahgunakan oleh laki-laki. Keempat perempuan mengalami perbedaan, ketimpangan dan berbagai penindasan berdasarkan posisi total mereka dalam susunan stratifikasi atau faktor penindasan dan hak istimewa berdasar kelas, ras, etnisitas, umur, status perkawinan, dan posisi global. Masing-masing berbagai tipe teori feminis itu dapat digolongkan sebagai teori perbedaan gender, atau 
teori ketimpangan gender, atau teori penindasan gender, atau teori penindasan sruktural. ${ }^{1}$

Sementara itu pemikiran Islam tradisional yang direfleksikan oleh kitab-kitab fiqh secara general memberikan keterbatasan peran perempuan sebagai istri dan ibu. Menurut pemikiran Islam tradisional tersebut bahwa prinsip utamanya adalah bahwa "lakilaki adalah kepala keluarga" dan bertanggung jawab terhadap persoalanpersoalan luar rumah, sedangkan perempuan sebagai istri, bertanggung jawab untuk membesarkan anak dan pelayananpelayanan domestik lainnya. Perbedaan ini menjadi titik tolak ukur dari perbedaan peran laki-laki dan perempuan

Berdasarkan pandangan teks dan literature Islam klasik tersebut masih terlihat bahwa kaum perempuan masih termarjinalkan, atau dengan kata lain perempuan masih berada di bawah dominasi lakilaki. Oleh karenanya, wacana atau konstruk perempuan harus menurut kehendak teks. Tak dapat dipungkiri bahwa penafsiran ulama-ulama klasik tentang konsep persamaan laki-laki dan perempuan jika dilihat dari perspektif saat ini bisa saja dinilai sebagai bias. Sebab penafsiran-penafsiran masa lampau itu tidak dapat dilepaskan dengan konteks sosio-historis saat itu. ${ }^{2}$

Berangkat dari permasalahan tersebut di atas maka tulisan ini ingin melihat dan menganalisa bagaimana konsep yang ditawarkan dan dikemukakan Islam dalam memandang kesetaraan gender antara laki-laki dan perempuan

\footnotetext{
${ }^{1}$ George Ritzer and Douglas J. Goodman, Modern Sociological Theory, $6^{\text {th }}$ Edition, diterjemahkan, Teori Sosiologi Modern, oleh Alimandan (Jakarta: Prenada Media, 2003), h:414-416

${ }^{2}$ Faisar Ananda Arfa, Wanita dalam Konsep Islam Modernis, (Jakarta: Pustaka Firdaus, 2004), .11
} 


\section{A. Konsep Gender}

Dalam bahasa Inggris, kata gender diartikan sebagai "jenis kelamin", atau sinonim dengan kata sex. Untuk konsep yang lebih luas, gender diartikan sebagai "gender is a basis for beginning the different contributions that man and woman make to culture and collective life by distinction which they are as man and woman." Sedangkan kesetaraan gender berarti kesamaan kondisi bagi lakilaki dan perempuan untuk memperoleh kesempatan serta hakhaknya sebagai manusia. Kesetaraan gender meliputi penghapusan diskriminasi dan ketidakadilan struktural, baik terhadap laki-laki maupun perempuan. Dengan keadilan gender berarti tidak ada pembakuan peran, beban ganda, subordinasi, marginalisasi dan kekerasan terhadap perempuan maupun laki-laki

Konsep penting yang perlu dipahami dalam rangka membahas hubungan kaum perempuan dan laki-laki adalah membedakan antara konsep sex (jenis kelamin) dan konsep gender. Pemahaman dan pebedaan antara kedua konsep tersebut sangat diperlukan dalam melakukan analisis untuk memahami persoalan-persoalan ketidakadilan sosial yang menimpa kaum perempuan. Hal ini disebabkan karena ada kaitan yang erat antara perbedaan gender (gender differences) dan ketidakadilan gender (gender inequalities) dengan struktur ketidakadilan masyarakat secara luas. Pemahaman atas konsep gender sangatlah diperlukan mengingat dari konsep ini telah lahir suatu analis gender. ${ }^{3}$

Istilah gender digunakan berbeda dengan sex. Gender digunakan untuk mengidentifikasi perbedaan laki-laki dan perempuan dari segi sosial-budaya. Sementara sex digunakan untuk mengidentifikasi perbedaan laki-laki dan perempuan dari segi

\footnotetext{
${ }^{3}$ Mansour Fakih, Analisis Gender dan Transformasi Sosial, (Yogyakarta: Pustaka Pelajar, 1997), 4.
} 
anatomi biologi. Istilah sex lebih banyak berkonsentrasi pada aspek biologi seseorang, meliputi perbedaan komposisi kimia dan hormon dalam tubuh, anatomi fisik, reproduksi, dan karakteristik biologis lainnya. Sementara itu, gender lebih banyak berkonsentrasi kepada aspek sosial, budaya, psikologis, dan aspek-aspek non-biologis lainnya. ${ }^{4}$

Perbedaan tersebut melahirkan pemisahan fungsi dan tanggung jawab antara laki-laki dan perempuan. Laki-laki bertugas mengurusi urusan luar rumah dan perempuan bertugas mengurusi urusan dalam rumah yang dikenal sebagai masyarakat pemburu (hunter) dan peramu (gatherer) dalam masyarakat tradisional dan sektor publik dan sektor domestik dalam masyarakat modern. ${ }^{5}$ Perbedaan gender (gender differences) pada proses berikutnya melahirkan peran gender (gender role) dan dianggap tidak menimbulkan masalah, maka tak pernah digugat. Akan tetapi yang menjadi masalah dan perlu digugat adalah struktur ketidakadilan yang ditimbulkan oleh peran gender dan perbedaan gender. ${ }^{6}$

Dalam pergaulan sehari-hari dalam masyarakat yang menganut perbedaan gender, ada nilai tata krama dan norma hukum yang membedakan peran laki-laki dan perempuan. Setiap orang seolaholah dituntut mempunyai perasaan gender (genderfeeling) dalam pergaulan, sehingga jika seseorang menyalahi nilai, norma dan perasaan tersebut maka yang bersangkutan akan menghadapi risiko di dalam masyarakat. Predikat laki-laki dan perempuan dianggap sebagai simbol status. Laki-laki diidentifikasi sebagai orang yang memiliki karekteristik kejantanan (masculinity), sedangkan perempuan diidentifikasi sebagai orang yang memiliki karekteristik kewanitaan (femininity). Perempuan dipersepsikan

\footnotetext{
${ }^{4}$ Nasaruddin Umar, Argumen Kesetaraan Jender Perspektif Al-Qur'an(Jakarta:

Paramadina, 1999), 35.

${ }^{5}$ Mansour Fakih., 302-302

${ }^{6}$ Nur Ahmad Fadhil Lubis, Yurisprudensi Emansipatif, (Bandung: Citapustaka Media, 2003). 47
} 
sebagai wanita cantik, langsing, dan lembut, sebaliknya laki-laki dipersepsikan sebagai manusia perkasa, tegar dan agresif.

Sementara perempuan ditempatkan pada posisi inferior. Peran mereka terbatas sehingga akses untuk memperoleh kekuasaan juga terbatas, akibatnya perempuan mendapatkan status lebih rendah dari laki-laki. Sebagai ibu atau sebagai istri mereka memperoleh kesempatan yang terbatas untuk berkarya di luar rumah. Penghasilan mereka sangat tergantung pada kerelaan laki-laki, meskipun bersama dengan anggota keluarganya merasakan perlindungan yang diperoleh dari suaminya hak-hak yang diperolehnya jauh lebih terbatas daripada hak-hak yang dimiliki suaminya. ${ }^{7}$

Menurut Ritzer dan Goodman, ada empat tema yang menandai teori ketimpangan gender. Pertama, laki-laki dan perempuan diletakkan dalam masyarakat tak hanya secara berbeda, tetapi juga timpang. Secara spesifik, perempunan memperoleh sumber daya material, status sosial, kekuasaan dan peluang untuk

mengaktualisasikan diri lebih sedikit daripada yang diperoleh lakilaki yang membagi-bagi posisi sosial mereka berdasarkan kelas, ras, pekerjaan, suku, agama, pendidikan, kebangsaan atau berdasarkan faktor sosial penting lainnya. Kedua, ketimpangan gender berasal dari organisasi masyarakat, bukan dari perbedaan biologis atau kepribadian penting antara laki-laki dan perempuan. Ketiga, meski manusia secara individual memiliki perbedaan ciri dan karakter satu sama lain, namun tidak ada pola perbedaan alamiah signifikan yang membedakan laki-laki dan perempuan. Pengakuan akan ketimpangan gender berarti secara langsung menyatakan bahwa perempuan secara situasional kurang berkuasa dibanding lakilaki untuk memenuhi kebutuhan mereka bersama laki-laki dalam rangka pengaktualisasian diri. Keempat,semua teori ketimpangan gender menganggap laki-laki maupun perempuan akan menanggapi situasi dan struktur sosial yang semakin mengarah ke

\footnotetext{
${ }^{7}$ Nasaruddin Umar., Op. Cit. , 75
} 
persamaan derajat (egalitarian) dengan mudah dan secara ilmiah. Dengan kata lain, mereka berkeyakinan akan adanya peluang untuk mengubah situasi. ${ }^{8}$

Kesetaraan antara laki-laki dan perempuan dalam sebuah keluarga, bukan berarti memposisikan laki-laki dan perempuan harus diperlakukan sama. Memperlakukan laki-laki dan perempuan secara sama dalam semua keadaan justru menimbulkan bias jender. Memperlakukan sama antara laki-laki dan perempuan dalam kerja rumah tangga pada satu keadaan, misalnya, suami juga berkewajiban mengurus anaknya, sama halnya istri mempunyai kewajiban mengurus anaknya. Artinya keajiban mengurus anak tidak mutlak menjadi kewajiban istri semata, tetapi merupakan kewajiban bersama.

Menurut Budhy Munawar Rachman, terjadinya bias gender salah satunya disebabkan tema patriarkhi (kekuasaan kaum lakilaki), yang hal ini menjadi agenda yang paling besar digugat oleh kaum feminisme Islam. Karena patriarhki dari sudut feminisme dianggap sebagai asal usul dari seluruh kecenderungan misoginis (kebencian terhadap kaum perempuan) yang mendasaripenulisanpenulisan teks keagamaan yang bias kepentingan laki-laki. ${ }^{9}$

Kekerasan terhadap perempuan selalu terjadi di antaranya disebabkan beberapa faktor yaitu:

1. Ideologi patriarkhi dan budaya patriarkhi. Di mana laki-laki superior (penguasa perempuan) dan perempuan inferior

2. Faktor struktur hukum yang meliputi substansi hukum (berisi semua peraturan perundang-undangan) baik tertulis maupun tidak tertulis yang berlaku bagi lembaga tinggi negara maupun

\footnotetext{
${ }^{8}$ George Ritzer and Douglas J. Goodman, Op. Cit. 420

${ }^{9}$ Budhy Munawar Rachman, Islam Pluralis Wacana Kesetaraan Kaum Beriman, (Jakarta: Paramadina),.394
} 
warga negara, struktur hukum (penegak hukum, polisi, jaksa, hakim, pengacara dan prosedur penegakannya), budaya hukum 3. Faktor interpretasi agama dan budaya ${ }^{10}$

Konsep patriarki berbeda dengan patrilinial. Patrilinial diartikan sebagai budaya di mana masyarakatnya mengikuti garis laki-laki seperti anak bergaris keturunan ayah, contohnya Habsah Khalik; Khalik adalah nama ayah dari Habsah. Sementara patriarki memiliki makna lain yang secara harfiah berarti "kekuasaan bapak" (role of the father) atau "partiakh" yang ditujukan untuk pelabelan sebuah "keluarga yang dikuasai oleh kaum laki-laki". Secara terminologi kata patriarki digunakan untuk pemahaman kekuasaan laki-laki, hubungan kekuasaan dengan apa laki-laki menguasai perempuan, serta sistem yang membuat perempuan tetap dikuasai melalui bermacam-macam cara. ${ }^{11}$

Lebih lanjut menurut Budhy secara etimologis konsep tersebut berkaitan dengan sistem sosial, dimana sang ayah menguasai semua anggota keluarganya, harta miliknya serta sumber-sumber ekonomi. Ia juga yang membuat semua keputusan penting keluarga. Sistem berdasarkan patriarkhi ini biasanya mengasingkan perempuan di rumah, dengan demikian laki-laki lebih bisa menguasai kaum perempuan. Sementara itu pengasingan perempuan di rumah menjadikan perempuan tidak tidak mandiri secara ekonomis, dan selanjutnya tergantung secara psikologis.

Norma-norma moral, sosial dan hukum pun lebih banyak memberi hak kepada kaum laki-laki daripada kaum perempuan, justru karena alasan bahwa kaum laki-laki memang lebih bernilai secara publik daripada perempuan. Dalam perkembangannya patriarkhi ini sekarang telah menjadi istilah terhadap semua sistem kekeluargaan maupun sosial, politik dan

\footnotetext{
${ }^{10}$ Elfi Muawanah, Menuju Kesetaraan Gender, (Malang: Kutub Minar, 2006), 144

${ }^{11}$ Kamala Bashin, What is Patriarchy, Diterjemahkan "Menggugat Patriarki" oleh Nursyahbani Katjasungkana, (Yogyakarta: Yayasan Bentang Budaya, 1996),. 29
} 
keagamaan yang merendahkan, bahkan menindas kaum perempuan mulai dari lingkungan rumah tangga hingga masyarakat. ${ }^{12}$

\section{B. Kesetaraan Gender dalam Perspektif Islam}

Pada dasarnya semangat hubungan antara laki-laki dan perempuan dalam Islam bersifat adil (equal). Oleh karena itu subordinasi terhadap kaum perempuan merupakan suatu keyakinan yang berkembang di masyarakat yang tidak sesuai atau bertentangan dengan semangat keadilan yang diajarkan Islam. Islam memang mengakui adanya perbedaan (distincion) antara laki-laki dan perempuan, tetapi bukan pembedaan (discrimination). Perbedaan tersebut didasarkan atas kondisi fisik-biologis perempuan yang ditakdirkan berbeda dengan laki-laki, namun perbedaan tersebut tidak dimaksudkan untuk memuliakan yang satu dan merendahkan yang lainnya. ${ }^{13}$

Ajaran Islam tidak secara skematis membedakan faktorfaktor perbedaan laki-laki dan perempuan, tetapi lebih memandang kedua insan tersebut secara utuh. Antara satu dengan lainnya secara biologis dan sosio kultural saling memerlukan dan dengan demikiann antara satu dengan yang lain masing-masing mempunyai peran. Boleh jadi dalam satu peran dapat dilakukan oleh keduanya, seperti perkerjaan kantoran, tetapi dalam peranperan tertentu hanya dapat dijalankan oleh satu jenis, seperti; hamil, melahirkan, menyusui anak, yang peran ini hanya dapat diperankan oleh wanita. Di lain pihak ada peran-peran tertentu yang secara manusiawi lebih

\footnotetext{
${ }^{12}$ Budhy Munawar Rachman, Op.cit.

${ }^{13}$ Nasaruddin Umar, Kodrat Perempuan dalam Islam, (Jakarta: Lembaga Kajian Agama dan Gender, 1999), 23
} 
tepat diperankan oleh kaum laki-laki seperti pekerjaan yang memerlukan tenaga dan otot lebih besar. ${ }^{14}$

Emansipasi wanita yang diperjuangkan oleh gerakan feminisme sebenarnya bukan barang baru dalam islam. Pada masa Rasulullah SAW, semangat feminisme juga sempat muncul ke permukaan. Wanita muslilmat pada saat itu menginginkan hak yang sama antara laki-laki dan perempuan. Ummu Salamah pernah mengadu kepada Rasul SAW dengan berkata, " wahai Rasulullah, Kaum pria ikut berperang sedangkan kita (wanita) tidak berperang, kita juga hanya mendapat separo warisan." Dalam tinta sejarah, pada akhirnya peristiwa ini menjadi sebab diturunkannya ayat ${ }^{15}$ :

Ayat ini menunjukkan bahwa islam dengan tegas menolak feminisme dan persamaan gender tanpa batas di segala bidang. Sebagai solusinya, islam mengambil langkah bijak dengan cara menunjukan dan mendudukkan wanita pada posisi yang sesuai dengan porsi kewanitaannya, sebagaimana islam mendudukkna kaum pria pada posisi yang sesuai.

Hadirnya agama Islam antara lain untuk menyelamatkan dan membembaskan kaum perempuan dari penindasan-penindasan dimasa jahiliyah. Al-qur'an turun untuk mengangkat harkat dan mertabat serta memberikan hak-hak bagi kaum wanita secara proposional dengan tanpa mengesampingkan nilai-nilai kodrati dalam dirinya. Bagi islam, diskriminasi merupalan sebuah tindakan kejahatan, akan tetapi upaya untuk kesetaraan merupakan bentuk kesesatan. Islam tidak pernah menganggap perempuan lebih rendah ataupun sama dengan laki-laki islam hanya menentukan hak-hak antara keduanya dalam porsi sesuai dengan alamiyah masingmasing. 16

\footnotetext{
${ }^{14}$ Ibid, 23

15 Ath-thobari, Tafsir ThobariI (Beirut:dar al fikr) vol. 5, 46-47

${ }^{16}$ Ath-thobari, Tafsir ThobariI (Beirut:dar al fikr) vol. 5, 48
} 
Imam al-fakhrur razi dalam tafsirnya, memaparkan beberapa faktor yang membedakan antara kaum pria dan wanita sesuai dengan kodrat masing-masing. Antara lain:

1. Laki-laki lebih mempunyai peluang untuk selalu bisa mengabdikan diri untuk beribadah kepada Allah, sedangkan kaum perempuan selalu terhalang dengan kodrat alamiahnya seperti adanya datang bulan (menstruasi/haid), melahirkan, menyusui dan faktor-faktor alamiyah lainnya

2. Dari faktor fisik dan psikologis, tipe laiki-laki dominan lebih kuat, tangguh, tegas dan berani dari pada wanita sehingga lakilaki mampu untuk mencari nafkah, bertanggung jawab, mengambil keputusan dan tugas-tugas yang dianggap lebih beresiko dan peerlu keteguhan jiwa.

3. Laki-laki lebih pantas untuk berinteraksi tanpa harus menanggung aib yang semua itu justru bertentangan dengan psikis dan tabiat wanita yang lemah lembut, penuh kasih sayang dan keibuan. ${ }^{17}$

Pada dasarnya islam tidak melarang kaum hawa untuk turut serta dalam berkarir dan berkerja. Karena mencari harta yang halal adalah suatu kewajiban. Syaikh Abdullah Hamid Al-Jalali menjelaskan adanya beberapa syarat yang harus dipenuhi oleh wanita dalam berkarir. Diantaranya wanita haruslah jauh dari pandangan pria dan percampuran lawan jenis, tidak menyendiri, tidak ada laki-laki selain mahram dan amannya dalam perjalanan. Kalau ada statement yang melarang wanita untuk berkarir karena faktor khauf al-fitnah demi menjaga harkat dan martabat wanita. ${ }^{18}$

Islam juga memberikan porsi peran publik yang sama antara pria dan wanita, karena semua di hadapan Allah SWT adalah sama.

\footnotetext{
${ }^{17}$ Al-fakhr al-raziy, tafsir fakhr al- raziy (Beirut:dar al-fikr) vol. 8, 28-29

${ }^{18}$ Abdullah Hamid Al-Jalali, Fiqh al-Islam vol. 2 (Beirut: Dar al-Fikr) 365
} 
Tetapi karena ada suatu fungsi yang berbeda antara keduanya dikarenakan faktor sex yang bereda mengharuskan keduanya menepati fungsinya masing-masing. Karena pertimbangan faktor alamiyah yang secar kodrati wanita mempunyai kewajiban melahirkan menyusui dan mengasuh anak serta kekurangan dalam hal fisik yang lembut dan bermental tipis (Naqishah al-Aqli), para Ulama tidak memperbolehkan wanita menempati posisi yang memerlukan potensi figur yang tegas berwibawa dan tangguh sebagaimana lembaga yudikatif. ${ }^{19}$

Penjelasan di atas memberikan pengertian bahwa ssebenarnya islam sangatlah menghargai dan menjunjung tinggi hak dan martabat kaum hawa. Hal ini sangatlah jelas bila kita mau menengok kembali sejarah kelas awal mula lahirnya islam dimana pada masa jahiliyah wanita disamakan dengan harta yangg bisa diwarits dan di pindah tangankan. Lebih dari itu, kelahiran seorang bayi wanita dianggap suatu aib sehingga masyarakat arab tega mengubur hiduphidup bayi perrempuannya.

Setelah islam datang seakan menjadi oase segar ditengah padang pasir luas yang mengajarkan persamaan derajat bahkan dalam konsep al-birr al-walidain, islam memberikan porsi tiga kali lipat kepada para ibu yang notabene perempuan untuk lebih dimuliakan dari pada laki-laki.

Tatanan rahmatan lil alamin yang di bawa Islam tidak mudah begitu saja gugur karena klai sepihak gerakan feminisme maupun adat yang bertentangan dengan Syara'. Karena tidak semua hal yang mengandung mashlahat dan kebaikan tidak dapat begitu saja di aplikasikan. Seperti halnya mashlahat yang terkandung dalam praktek riba, arak dan judi.

Konsep Islam menyumbangkan suatu sistem sosial yangadil terhadap kaum perempuan. Islam memandang perempuan adalah sama dengan laki-laki dari segi kemanusiannya. Islam memberi hak-

${ }^{19}$ Wahbah az-Zuhaili, Fiqh al-Islamiy wa Adilatuh vol. 6 (Beirut :Dar al-Fikr, 1989) 486 
hak kepada perempuan sebagaimana yang diberikan kepada kaum laki-laki dan membebankan kewajiban yang sama kepada keduanya. Ajaran Islam tidak secara skematis membedakan faktorfaktor perbedaan laki-laki dan perempuan, tetapi lebih memandang kedua insan tersebut secara utuh. Antara satu dengan lainnya secara biologis dan sosio kultural saling memerlukan dan dengan demikian antara satu dengan yang lain masing-masing mempunyai peran. 


\section{Daftar Pustaka}

Abdullah Hamid Al-Jalali, Fiqh al-Islam (Beirut: Dar al-Fikr)

Al-fakhr al-raziy, tafsir fakhr al- raziy (Beirut:dar al-fikr)

Ath-thobari, Tafsir ThobariI (Beirut:dar al fikr)

Budhy Munawar Rachman, Islam Pluralis Wacana Kesetaraan Kaum Beriman, (Jakarta: Paramadina)

Elfi Muawanah, Menuju Kesetaraan Gender, (Malang: Kutub Minar, 2006), 144

Faisar Ananda Arfa, 2004, Wanita dalam Konsep Islam Modernis, (Jakarta: Pustaka Firdaus)

George Ritzer and Douglas J. Goodman, 2003, Modern Sociological Theory, $6^{\text {th }}$ Edition, diterjemahkan, Teori Sosiologi Modern, oleh Alimandan (Jakarta: Prenada Media)

Mansour Fakih, 1997, Analisis Gender dan Transformasi Sosial, (Yogyakarta: Pustaka Pelajar)

Nasaruddin Umar, 1999, Argumen Kesetaraan Jender Perspektif AlQur'an (Jakarta: Paramadina).

Nur Ahmad Fadhil Lubis, Yurisprudensi Emansipatif, (Bandung: Citapustaka Media, 2003) . 47

Kamala Bashin, 1996, What is Patriarchy, Diterjemahkan 
"Menggugat Patriarki" oleh Nursyahbani Katjasungkana, (Yogyakarta: Yayasan Bentang Budaya)

Nasaruddin Umar, Kodrat Perempuan dalam Islam, 1999, (Jakarta: Lembaga Kajian Agama dan Gender)

Wahbah az-Zuhaili, 1989, Fiqh al-Islamiy wa Adilatuh (Beirut :Dar al-Fikr 